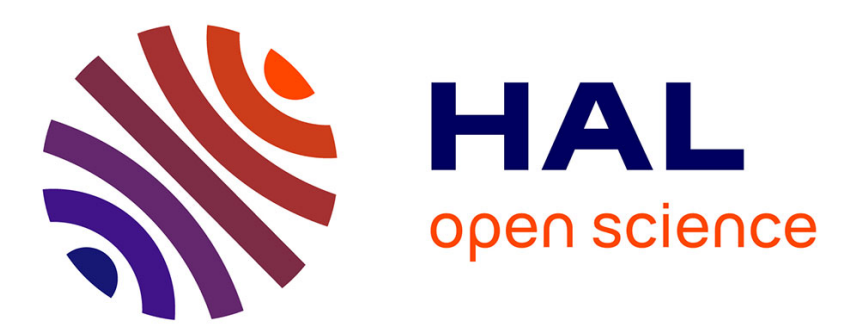

\title{
Enhancing Virtual Learning by Improving the Learning Environment and User Experience
}

\author{
Nicholas Mavengere, Mikko Ruohonen
}

\section{To cite this version:}

Nicholas Mavengere, Mikko Ruohonen. Enhancing Virtual Learning by Improving the Learning Environment and User Experience. 1st International Conference on Sustainable ICT, Education, and Learning (SUZA), Apr 2019, Zanzibar, Tanzania. pp.125-134, 10.1007/978-3-030-28764-1_15 . hal02515732

\section{HAL Id: hal-02515732 \\ https://hal.inria.fr/hal-02515732}

Submitted on 23 Mar 2020

HAL is a multi-disciplinary open access archive for the deposit and dissemination of scientific research documents, whether they are published or not. The documents may come from teaching and research institutions in France or abroad, or from public or private research centers.
L'archive ouverte pluridisciplinaire HAL, est destinée au dépôt et à la diffusion de documents scientifiques de niveau recherche, publiés ou non, émanant des établissements d'enseignement et de recherche français ou étrangers, des laboratoires publics ou privés.

\section{(c)(1)}

Distributed under a Creative Commons Attribution| 4.0 International License 


\title{
Enhancing Virtual Learning by Improving the Learning Environment and User Experience
}

\author{
Nicholas Mavengere and Mikko Ruohonen ${ }^{0000-0002-9454-6068}$ \\ University of Tampere, Kalevantie 4, FI-33014 Tampere, Finland \\ nicholas.mavengere@tuni.fi, mikko.ruohonen@tuni.fi
}

\begin{abstract}
Learning is an essential virtue in a dynamic environment. Technologies offer both opportunities and challenges to learning. The global nature of the environment today calls for virtual learning, which offers dimensions, such as, convenience, time and cost factors. This research seeks to promote virtual learning experience by improving the learning environment and user experience. The research is based on a total virtual learning experience of a masters' level information and communication technology for development (ICT4D) class at the University of Tampere. A survey was conducted at the mid-course stage to assess the virtual learning experience and propose ways to improve learning process. The assessment included how well the virtual environment and pedagogy promoted quality learning, that is, constructive, collaborative and conversational learning. The research seeks to promote quality learning by improving the learning environment and participants' virtual learning experience. That is, context is embraced to map the learning process that suits the learners and study contents. The results of this study included highlight of pedagogical techniques and technological tools that fit the learners' and study content requirements to foster learning in a virtual environment.
\end{abstract}

Keywords: virtual learning, user needs in virtual learning, context in virtual learning, virtual learning review, quality learning

\section{Introduction}

The advances in technologies, for example, mobile and cloud based technologies offers opportunities for enhancing learning. The need to embrace innovative teaching practices to enhance the learning process by adopting new technologies and pedagogical practices has been called for, some time now. For example, twenty years ago Leidner and Jarvenpaa [3] advocated for information technology (IT) use to improve business management school. However, the continuously changing technology and educational practices mean that this call for research to improve the learning process will always be required. In addition, factors such as globalization are also influencing the educational environment. In fact, virtual learning in different set ups, such as blended and wholly virtual approach, has been widely adopted. 
The advantages of virtual learning have been well documented. For example, Chou and Liu [6] noted the potential of virtual learning in eliminating barriers and increasing flexibility, convenience, student retention, individual learning, convenience, currency of material and feedback. However, there are also related disadvantages, such as, possibility of participants' feeling isolated thus leading to anxiety and confusion thus reducing learning effectiveness. Therefore, it is important to embrace virtual learning to try to maximize the benefits gained, as well as to reduce the negative impacts [5]. One way of doing that, is in understanding context and students' needs as users of the virtual learning environment. Oxford dictionary defines context as the circumstances that form the setting for an event and in terms of which it can be fully understood. In this research context refers to the circumstances that form the setting of virtual learning course, such as, learning model, students' virtual learning experience and study contents. This study seeks to highlight ways in which context and user needs are considered in mapping pedagogical practices and technological tools in pursuit of quality learning. Quality learning is elaborated in the next section, theoretical background. Thus, the research question is; how could context and user needs to promote quality learning in virtual learning?

The research is based on a total virtual learning experience of a masters' level information and communication technology for development (ICT4D) course hosted at the University of Tampere. A survey was conducted at the mid-course stage to assess the virtual learning experience and propose ways to improve learning process. Details of the course and survey are in the methodology section below. The research seeks to promote quality learning by considering context and user needs. That is, context is understood to map the learning process that suits the learners and study contents. The results of this study include highlight of pedagogical techniques and technological tools that fit the learners' and study content requirements to foster learning in a virtual environment. These pedagogical techniques and technological tools that promote quality learning are proposed in this study. Such techniques and tools has to fit the learning context, for instance, in the ICT4D course adoption was a result of the mid-course virtual learning review. Hence, context is argued to be reviewed and thereafter recommendations on specific pedagogical techniques and technological tools to be adopted. For instance, mid-course review could be way to draw appropriate measures for virtual learning.

The next section elaborates the theoretical basis of this research. For example, qualities of learning also referred to as quality learning in this research is elaborated, as well as, the learning models. After that, the methodology section, describes the ICT4D course the survey conducted. Then, the research findings are highlighted, followed by discussion and conclusion.

\section{Theoretical Background}

We should always strive for the best. There are fundamental aspects of learning, referred to as quality learning which we should always seek to achieve. These are the 
cornerstones which technology could aid to build upon to foster the learning process. Ruokamo and Pohjolainen [4] suggested the following qualities of learning;

1. Active - Learners' role in learning process is active; they are engaged in mindful processing of information and they are responsible for the result.

2. Constructive - Learners construct new knowledge on the basis of their previous knowledge.

3. Collaborative - Learners work together in building new knowledge in cooperation with each other and exploiting each other's skills.

4. Intentional - Learners try actively and willingly to achieve a cognitive objective.

5. Contextual - Learning tasks are situated in a meaningful real world tasks or they are introduced through case-based or problem-based real life examples.

6. Transfer - Learners are able to transfer learning from the situations and contexts, where learning has taken place and use their knowledge in other situations.

7. Reflective - Learners articulate what they have learned and reflect on the processes and decisions entailed by the process.

These learning qualities were evaluated in the survey, which was conducted in the ICT4D course. This was done in order to adopt technological tools and pedagogical practices that promote the above-mentioned qualities of learning. Please see methodology section below for more information about the survey.

Jarvenpaa and Leidner, [6] suggested that "the effectiveness of information technology in contributing to learning will be a function of how well the technology supports a particular model of learning and the appropriateness of the model to a particular learning situation”. Therefore, it is important to draw the specific learning model and ways to effectively use the learning technologies. Table 1 illustrates some learning models, please note this is not exhaustive but highlights some of the models.

Table 1. Summary of learning models adopted from Jarvenpaa and Leidner [6]

\begin{tabular}{|c|c|c|c|c|}
\hline Model & Basic Premise & Goals & $\begin{array}{l}\text { Major } \\
\text { Assumptions }\end{array}$ & $\begin{array}{l}\text { Implications for } \\
\text { Instruction }\end{array}$ \\
\hline Objectivism & $\begin{array}{l}\text { Learning is the } \\
\text { uncritical } \\
\text { absorption of } \\
\text { objective } \\
\text { knowledge. }\end{array}$ & $\begin{array}{l}\text { Transfer of } \\
\text { knowledge from } \\
\text { instructor to } \\
\text { student. } \\
\text { Recall of } \\
\text { knowledge. }\end{array}$ & $\begin{array}{l}\text { Instructor houses } \\
\text { all necessary } \\
\text { knowledge. } \\
\text { Students learn } \\
\text { best in isolated } \\
\text { and intensive } \\
\text { subject matter. }\end{array}$ & $\begin{array}{l}\text { Instructor is in } \\
\text { control of material } \\
\text { and pace. } \\
\text { Instructor provides } \\
\text { stimulus. }\end{array}$ \\
\hline Constructivism & $\begin{array}{l}\text { Learning is a } \\
\text { process of } \\
\text { constructing } \\
\text { knowledge by an } \\
\text { individual. }\end{array}$ & $\begin{array}{l}\text { Formation of } \\
\text { abstract concepts } \\
\text { to represent } \\
\text { reality. } \\
\text { Assigning } \\
\text { meaning to events }\end{array}$ & $\begin{array}{l}\text { Individuals learn } \\
\text { better when they } \\
\text { discover things } \\
\text { themselves and } \\
\text { when they control } \\
\text { the pace of } \\
\text { learning. }\end{array}$ & $\begin{array}{l}\text { Learner-centered } \\
\text { active learning. } \\
\text { Instructor for } \\
\text { support rather than } \\
\text { direction. }\end{array}$ \\
\hline
\end{tabular}




\begin{tabular}{|c|c|c|c|c|}
\hline & & and information. & & \\
\hline Collaborativism & $\begin{array}{l}\text { Learning emerges } \\
\text { through shared } \\
\text { understandings of } \\
\text { more than one } \\
\text { learner. }\end{array}$ & $\begin{array}{l}\text { Promote group } \\
\text { skills- } \\
\text { communication, } \\
\text { listening, } \\
\text { participation. } \\
\text { Promote } \\
\text { socialization. }\end{array}$ & $\begin{array}{l}\text { Involvement is } \\
\text { critical to } \\
\text { learning. } \\
\text { Learners have } \\
\text { some prior } \\
\text { knowledge. }\end{array}$ & $\begin{array}{l}\text { Communication } \\
\text { oriented. } \\
\text { Instructor as } \\
\text { questioner and } \\
\text { discussion leader. }\end{array}$ \\
\hline $\begin{array}{l}\text { Cognitive } \\
\text { Information } \\
\text { Processing }\end{array}$ & $\begin{array}{l}\text { Learning is the } \\
\text { processing and } \\
\text { transfer of new } \\
\text { knowledge into } \\
\text { long-term } \\
\text { memory. }\end{array}$ & $\begin{array}{l}\text { Improve cognitive } \\
\text { processing } \\
\text { abilities of } \\
\text { learners. } \\
\text { Improve recall } \\
\text { and retention. }\end{array}$ & $\begin{array}{l}\text { Limited selective } \\
\text { attention. } \\
\text { Prior knowledge } \\
\text { affects level of } \\
\text { instructional } \\
\text { support needed. }\end{array}$ & $\begin{array}{l}\text { Aspects of stimulus } \\
\text { can affect attention. } \\
\text { Instructors need } \\
\text { feedback on student } \\
\text { learning. }\end{array}$ \\
\hline Socioculturism & $\begin{array}{l}\text { Learning is } \\
\text { subjective and } \\
\text { individualistic. }\end{array}$ & $\begin{array}{l}\text { Empowerment. } \\
\text { Emancipatory } \\
\text { learning. } \\
\text { Action-oriented, } \\
\text { socially conscious } \\
\text { learners with a } \\
\text { view to change } \\
\text { rather than accept } \\
\text { or understand } \\
\text { society }\end{array}$ & $\begin{array}{l}\text { Anglos have } \\
\text { distorted } \\
\text { knowledge and } \\
\text { framed } \\
\text { information in } \\
\text { their own terms. } \\
\text { Learning occurs } \\
\text { best in } \\
\text { environments } \\
\text { where personally } \\
\text { well known. }\end{array}$ & $\begin{array}{l}\text { Instruction is always } \\
\text { culturally value } \\
\text { laden. } \\
\text { Instruction is } \\
\text { embedded in a } \\
\text { person's everyday } \\
\text { cultural/social } \\
\text { context. }\end{array}$ \\
\hline
\end{tabular}

In the ICT4D course is based on the constructivism model and its derivations, that is, collaborativism and cognitive information processing. This is in line with Ruokamo and Pohjolainen [4] who argued that constructivism is increasingly an essential theory in in the research of technology-based learning.

\section{$3 \quad$ Methodology}

The University of Tampere hosted an international virtual course with participants from Finland, Germany, and South Africa. The course topic was Development 2.0, that is, Information Communications Technologies for Development 2.0. The course comprised of 33 participants who had diverse virtual learning experience as illustrated in Figure 1. About $50 \%$ of the participants had 5 or more times of virtual learning experience.

A survey was conducted at the middle of the course. The objectives in conducting the survey included reviewing the virtual learning experience for the class and adopting measures, pedagogical, technology tools and practices to enhance virtual learning. The Figure 3 below illustrates the virtual experience in the first half of the course. This figure is a normal curve, which illustrates above satisfactory view to the virtual experience in the class, with $57 \%$ regarding the experience as very good. 


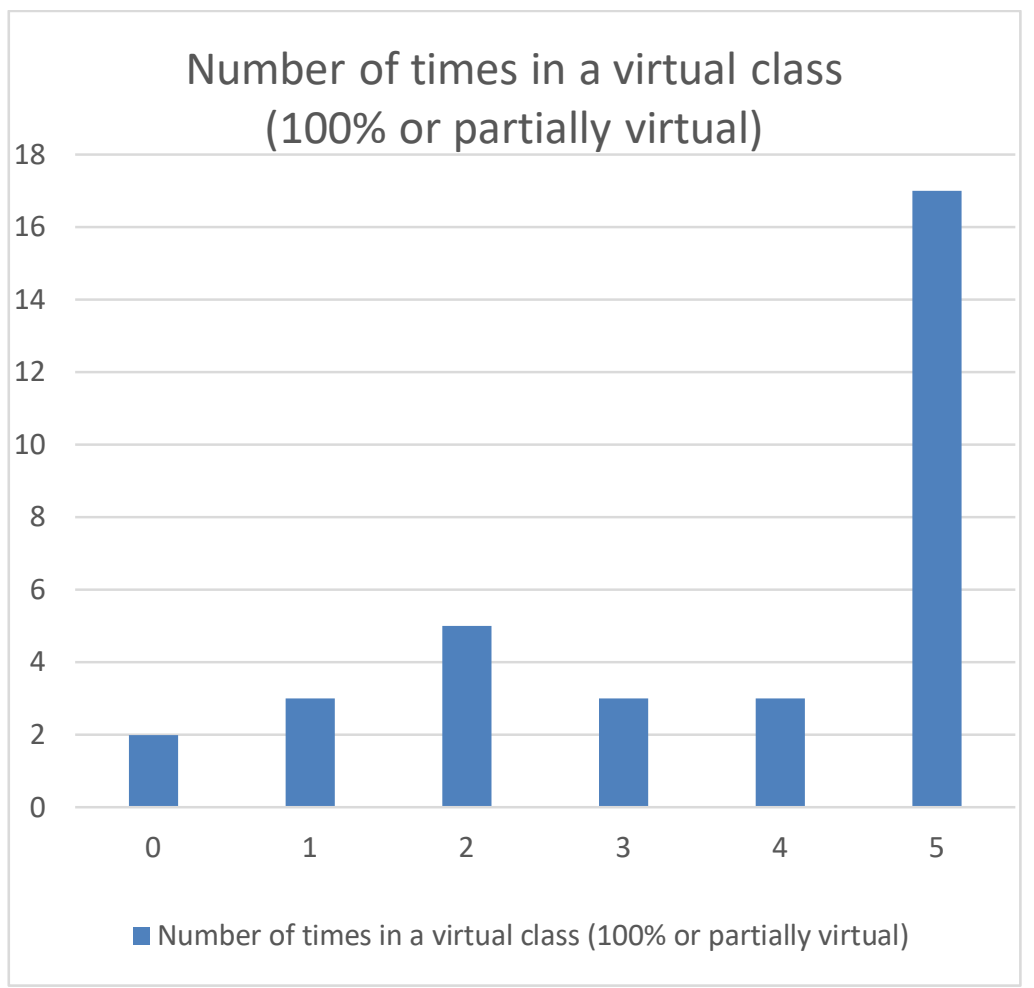

Fig. 1. Virtual learning experience

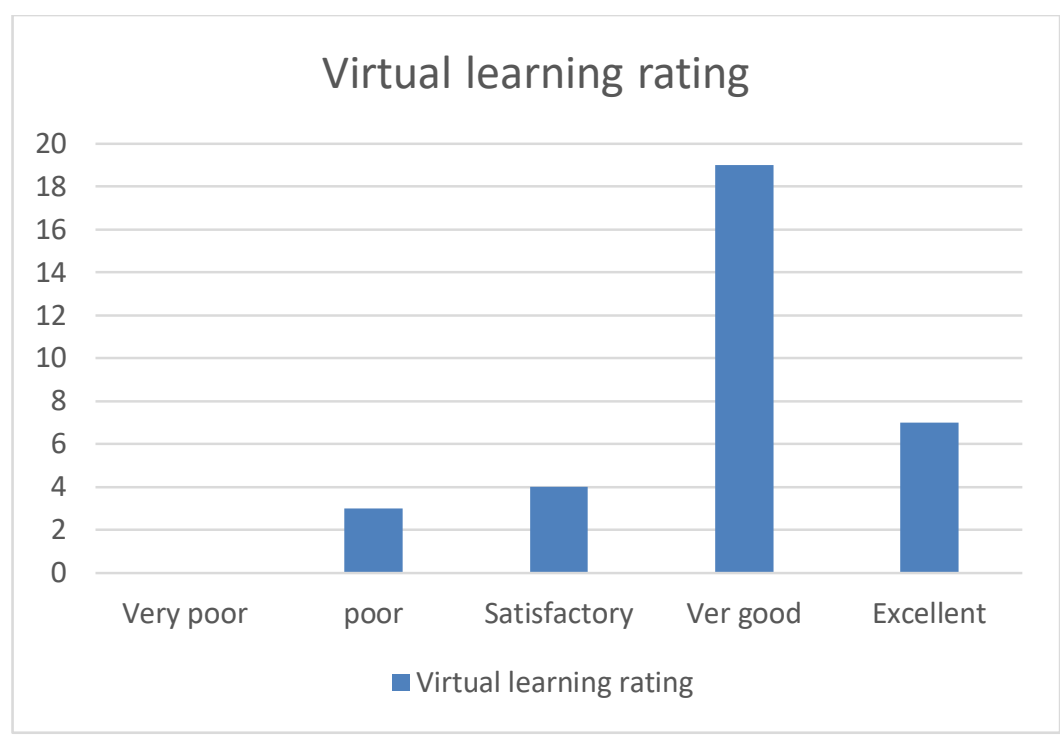

Fig. 2. Virtual learning experience rating 
Figure 2 illustrate that the virtual learning experience was very good but the qualitative review showed that there were some specific gaps which needs to be addressed. For instance, several participants highlighted the need for more interaction, as shown in the quotes below,

"I would prefer the learning to be more interactive. Now communication is rather one sided and only between the course teacher and the participant”.

"I appreciate the strict deadline which I have to abide by, though I failed once, since it offers me with a structured guideline to follow the course so I can regularly schedule my time to think about the topic. In contrast, I would have preferred an occasional group chat platform (due to varying study schedules of all the participants) that is more conducive to dynamic interaction amongst us, rather than individual reflection, although the latter is prerequisite to the former”.

Thus, some measures to improve the virtual learning experience were implemented. These are described in the next section.

\section{$4 \quad$ Results}

The types of material used in the first half of the course were assessed to determine their suitability to the virtual learning environment. Figure 3 below illustrates how the learners evaluated the material. All the material were generally valued quite high except books.

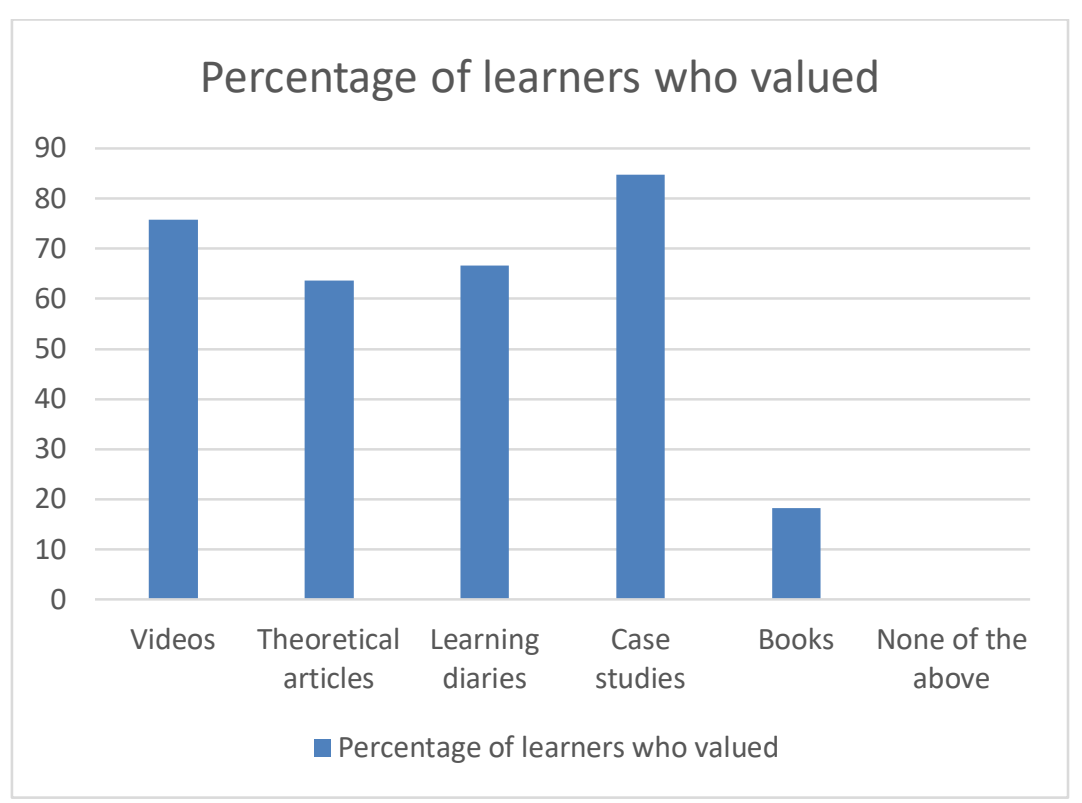

Fig. 3. Evaluation of material types used in virtual learning 
There were also technology applications that were proposed for adoption in the course. Figure 4 shows learners' acceptance rate of new applications adoptions. Online discussion forum is most desired for adoption as one student noted "online discussion where we even allow to raise question and put opinion”

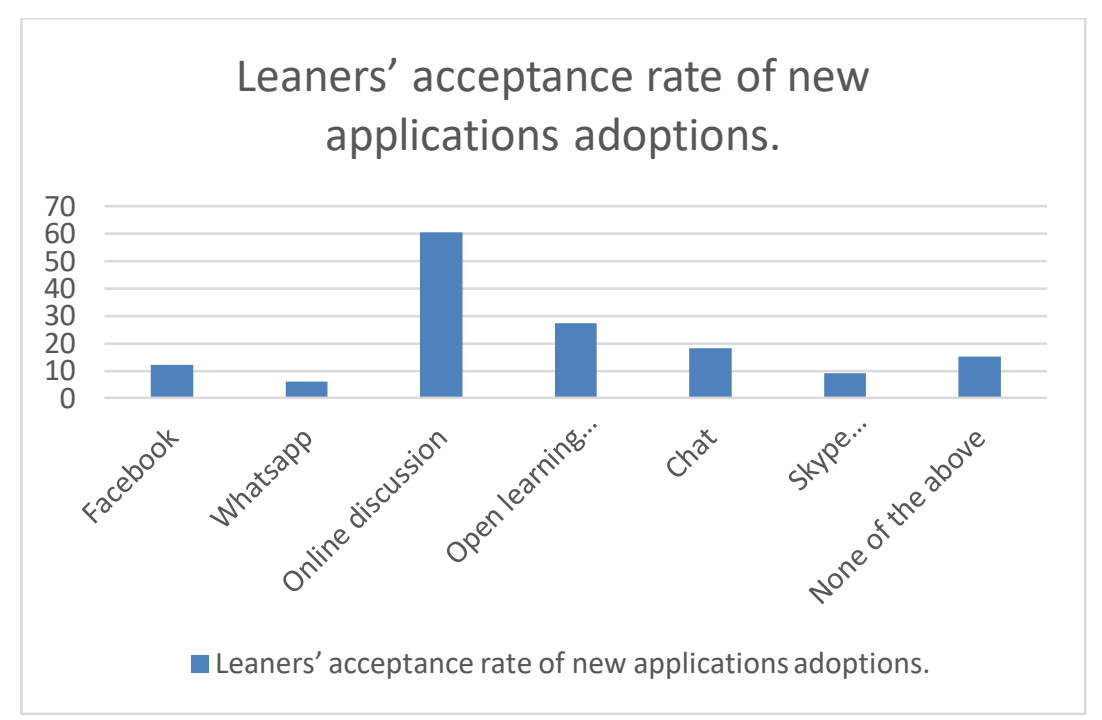

Fig. 4. Leaners' acceptance rate of new applications adoptions.

Assessment techniques are also evaluated as shown in Figure 5. Learning diary and essay were the most preferred assessment techniques. All the other assessment techniques are below $50 \%$. 


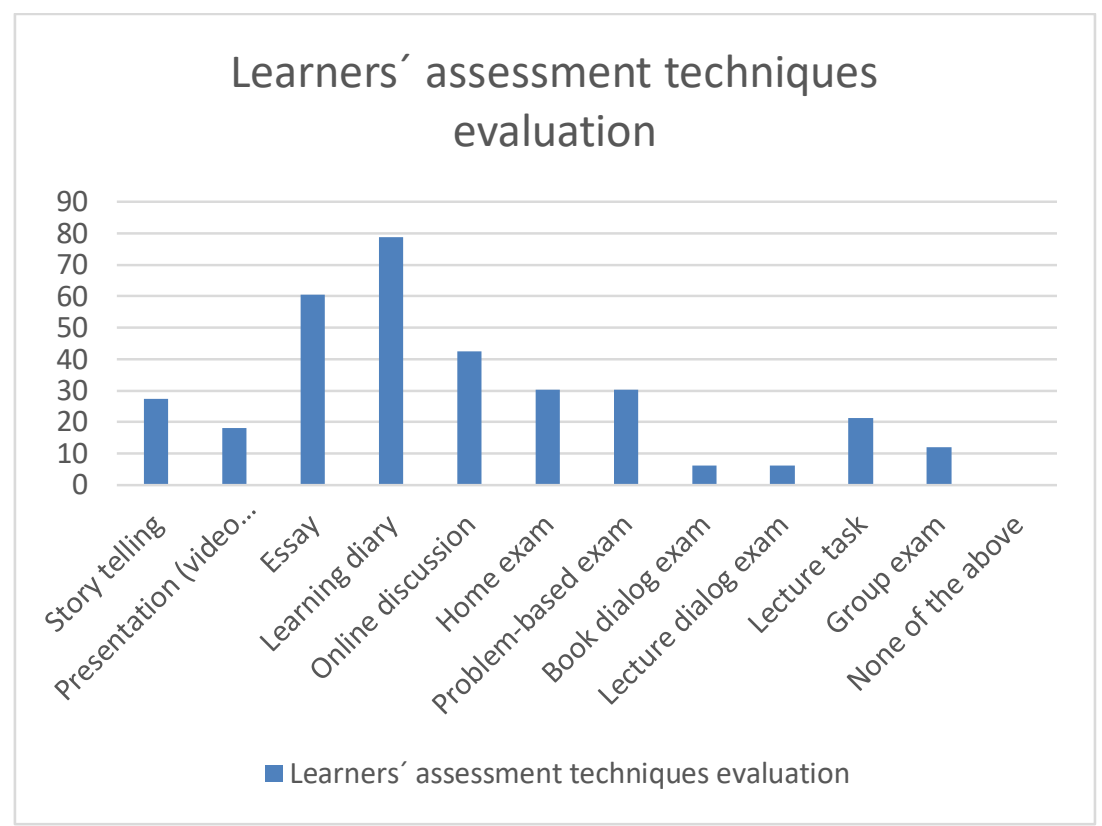

Fig. 5. Learners' assessment techniques evaluation

The qualities of learning proposed by Ruokamo and Pohjolainen [4] were also evaluated as shown in Figure 6. Only two qualities of learning namely constructive and contextualized are above 50\%. This means that efforts, in terms of pedagogy and supporting technologies, needed to be enforced in pursuit of the quality learning, these are highlighted in the next section, discussion.

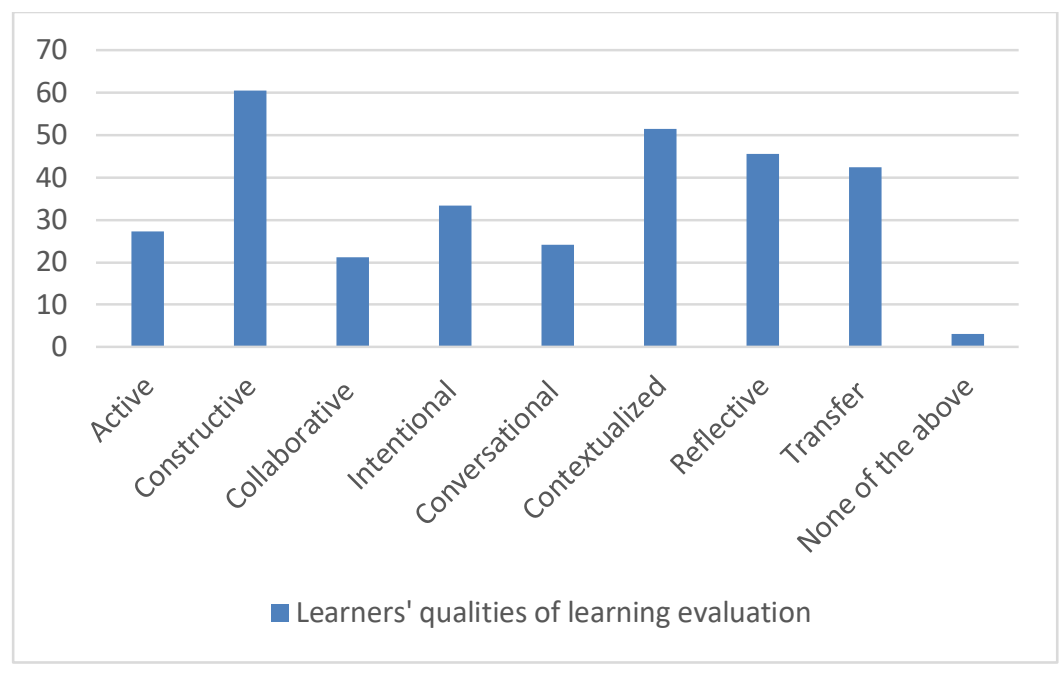

Fig. 6. Qualities of learning evaluation 


\section{Discussion}

The constructivist model of learning perceives learning as "the formation of abstract concepts to represent reality; learning is that which "decentrizes" the individual from the material. Learning is reflected in intellectual growth that leads to scientific reasoning, abstract thought, and formal operations" (Jarvenpaa and Leidner, 1995, p. 267). Thus constructivist model centers learning on the learner and advocates for a learning environment that forces learners to discover things themselves unlike when instructed. In the ICT4D course activities, such as, open learning diary encourages participants to share their experience in constructing meaning of the study contents. This relates to the cooperative model of learning or collaborativism. In addition, the ICT4D course also included group work to develop a wiki of a book, Frugal Innovation by Navi Radjou and Jaideep Prabhu. Halvorson et al. [2] advocated for active and participatory learning.

Table 2. Pedagogical technique and technological tools that promote qualities of learning

\begin{tabular}{|l|l|l|}
\hline $\begin{array}{l}\text { Quality of } \\
\text { learning }\end{array}$ & $\begin{array}{l}\text { Pedagogical techniques } \\
\text { promoting }\end{array}$ & Technological tools promoting \\
\hline Active & Group discussions & Online chat rooms \\
\hline Constructive & Group book summary & Wiki \\
\hline Collaborative & Team work & Video-conferencing \\
\hline Intentional & Open leaning diaries & Discussion forum \\
\hline Contextual & Case studies & Wiki \\
\hline Transfer & $\begin{array}{l}\text { Peer and self-assessment } \\
\text { workshops }\end{array}$ & Gamification \\
\hline Reflective & Essays & Discussion forum \\
\hline
\end{tabular}

Table 2 illustrates examples of pedagogical practices and technological tools that were adopted in the ICT4D course to promote quality learning. It is important to highlight that context and user needs were assessed which lead to the adoption of these pedagogical practices and technological tools. One important pedagogical practice that promote most of the qualities of learning is formulating groups and actively promote group work. This will encourage interaction within the participants and create atmosphere where participants could learn from each other. This is important in virtual learning environment which has high risk of participants feeling isolated. There are many different ways to integrate discussion forums, for instance, participants initiated forums promote intentional learning.

\section{Conclusion}

The integration of technology to promote learning will always be a burning issue because of the potential offered by the ever-evolving technologies. In addition, technology offers virtual learning possibility, which has advantages of convenience 
and flexibility. This research advocates for understanding the context and user needs to foster quality learning. Excellence should always be sort in learning, thus this research highlights attempts in pursuit of quality learning, that is, active, constructive, collaborative, intentional, contextual, transfer, reflective learning.

\section{Reference}

1. Chou S, Liu C: Learning effectiveness in a Web-based virtual learning environment: a learner control perspective, Journal of Computer Assisted Learning 21, pp. 65-76 (2005)

2. Halvorson w, Crittenden V, Pitt L.: Teaching Cases in a Virtual Environment: When the Traditional Case Classroom is Problematic, Decision Sciences Journal of Innovative Education, Volume 9 Number 3, p. 485 - 492 (2011)

3. Leidner, D.E. and Sirkka L. Jarvenpaa.: The Use of Information Technology to Enhance Management School Education: A Theoretical View, MIS Quarterly, Vol. 19, No. 3, pp. 265-291 (1995)

4. Ruokamo, H. \& Pohjolainen, S.: Pedagogical Principles for Evaluation of HypermediaBased Learning Environments in Mathematics. In JUCS -Journal of Universal Computer Science, 4 (3), 292-307 (1998)

5. Jonassen, D., Howland, J., Marra, R., Crismond, D.: Meaningful learning with technology (3rd ed.). Upper Saddle River, NJ: Pearson Merrill Prentice Hall Publishing (2008) 